\title{
MAPA ZAGROŻEŃ \\ PRZESTĘPSTWAMI NA TLE SEKSUALNYM JAKO INSTRUMENT SYTUACYJNEJ PREWENCJI PRZESTĘPCZOŚCI W POLSCE - UWAGI KRYTYCZNE
}

\section{PRZEDMIOT BADAŃ KRYMINOLOGII ŚRODOWISKOWEJ}

Teza, że czynniki środowiskowe - tj. zewnętrzne, oddziałujące na człowieka - wpływaja na zachowanie ludzi, nie jest obecnie szczególnie kwestionowana $\mathrm{w}$ nauce kryminologii ${ }^{1}$. Badaniem tego wpływu i zależności między przestępczością a środowiskiem przestrzennym, w którym funkcjonuje człowiek, zajmuje się kryminologia środowiskowa (ang. environmental criminology) ${ }^{2}$. Rozwój badań w tej dziedzinie związany jest w zasadniczej mierze z dokonaniami tzw. szkoły chicagowskiej w socjologii, której przedstawicielami byli m.in. Robert Park, Ernest Burgess, Cliford Shaw i Henry McKay. Najistotniejsza konstatacją pierwszego z wymienionych autorów było zwrócenie uwagi na fakt, że zmiany nasilenia przestępczości moga być wynikiem przekształceń środowiska fizycznego i przestrzeni społecznej ${ }^{3}$. Koncepcję sformułowaną wcześniej przez Parka ${ }^{4}$ potwierdziły badania Burgessa, który wskazywał, że społeczne interakcje wśród ludzi (m.in. konkurencja) prowadza do powstania w miastach specyficznej struktury przestrzennej, w której „lepsze” miejsca zajmują jednostki i grupy silniejsze, bardziej przedsiębiorcze, natomiast słabsi i mniej zaradni sa „spychani” do gorszych stref i obszarów $w^{5}$ Z kolei w badaniach nad przestępczością nieletnich Shaw i McKay zwrócili uwagę na nierównomierne nasilenie przestępczości nieletnich na terenie Chicago - największe w strefie centralnej, słabnące w miarę przechodzenia do stref zewnętrznych. Ponieważ taki stan rzeczy utrzymywał się na badanym obszarze przez 30 lat, mimo że skład ludnościowy poszczególnych stref uległ w ciagu tego czasu istotnej zmianie, autorzy sformułowali wniosek, iż na nasilenie przestępczości nieletnich decydujący wpływ ma charakter środowiska (specyficzne przeznaczenie każdej ze stref, związane

${ }^{1}$ J. Błachut, A. Gaberle, K. Krajewski, Kryminologia, Gdańsk 1999, s. 103.

2 A. E. Bottoms, P. Wiles, Environmental Criminology, w: M. Maguire, R. Morgan, R. Reiner (eds.), The Oxford Handbook of Criminology, 3rd edn., Oxford 2002, s. 620-656.

${ }^{3}$ J. Błachut, A. Gaberle, K. Krajewski, op. cit., s. 104 i 105.

${ }^{4}$ R. E. Park, Human Communities, New York 1952, s. 148, za: A. Siemaszko, Społeczna geneza przestępczości, Warszawa 1979, s. 20.

${ }^{5}$ A. Siemaszko, op. cit., s. 20 i 21. 
z nim przyjęte rozwiązania urbanistyczne, jak również zróżnicowanie kulturowe - m.in. różne systemy wartości, normy) i wynikające z niego różnice w standardach i formach zachowania ${ }^{6}$.

W toku późniejszego rozwoju kryminologii środowiskowej badania prowadzone były w dwóch zasadniczych kierunkach. Z jednej strony podejmowano próby oznaczenia miejsc lub obszarów, gdzie najczęściej popełniane były przestępstwa (lub przestępstwa określonego rodzaju), z drugiej zaś - dążono do ustalenia stref, z których wywodzą się i w których mieszkają ich sprawcy. Dokonanie takiego rozróżnienia stało się konieczne ze względu na krytykę, z jaką spotkały się pierwsze wnioski formułowane przez badaczy, za zakładanie a priori, że obszary o znacznym nasileniu przestępczości cechują się równocześnie stanem daleko posuniętej dezorganizacji społecznej

Użytecznym narzędziem wykorzystywanym we wspomnianych badaniach były mapy przestępczości. Na podstawie danych ze statystyk kryminalnych nanoszono informacje dotyczące miejsc popełnienia przestępstwa (lub miejsc zamieszkania sprawców) na mapy obszarów, których dotyczyły badania. W ten sposób powstawały mapy, które wskazywały, w jakich miejscach występuje największe nasilenie przestępczości, a także jakie tereny zamieszkane były w największej części przez osoby popełniające przestępstwa ${ }^{8}$. Trzeba podkreślić, że wspomniane narzędzia nie były tworzone wyłącznie dla celów poznawczych. Istotą tego rodzaju informacji było następnie poddawanie ich analizie w celu opracowania skutecznych metod prewencji przestępczości. Stały się one również podstawą do formułowania teorii kryminologicznych, w szczególności w zakresie etiologii przestępczości. Warto w tym kontekście wspomnieć choćby o teorii działań rutynowych ${ }^{9}$, według której przestępstwo jest wynikiem zbiegu - w jednym czasie i miejscu - trzech elementów: potencjalnego sprawcy (tj. osoby potencjalnie chętnej i zmotywowanej do popełnienia przestępstwa), odpowiedniego celu (tj. atrakcyjnego i wartościowego dla sprawcy) oraz braku odpowiedniego „strażnika” wybranego przez sprawcę celu ${ }^{10}$. W świetle tej koncepcji ludzie w ramach swoich codziennych zajęć i aktywności tworzą „sieć” nieformalnej kontroli społecznej, powstrzymujac tym samym potencjalnych przestępców od łamania prawa. Gdy jednak tej kontroli zabraknie bądź też ulegnie ona z jakichś przyczyn rozluźnieniu, zwiększa się prawdopodobieństwo zaistnienia przestępstwa ${ }^{11}$.

\footnotetext{
${ }^{6}$ J. Błachut, A. Gaberle, K. Krajewski, op. cit., s. 105.

${ }^{7}$ Por. A. E. Bottoms, P. Wiles, op. cit., s. 625; J. Błachut, A. Gaberle, K. Krajewski, op. cit., s. 106.

${ }^{8}$ Zob. m.in. P. M. Cozens, Urban planning and environmental criminology: towards a new perspective for safer cities, „Planning Practice \& Research” 26(4), 2011, s. 481-508; P. J. Brantingham, P. L. Brantingham, Environmental Criminology, Beverly Hills 1981; eidem, Patterns in Crime, New York 1984, s. 362.

${ }^{9} \mathrm{M}$. Felson, Linking criminal choice, routine activities, informal control and criminal outcomes, w: K. Moss (ed.), Crime Reduction. Critical Concepts in Criminology, vol. 2: Motivation of the Criminal Inclination, New York 2009, s. 169 i n.

10 „Strażnikiem” są osoby sprawujące nieformalną kontrolę społeczną w określonym czasie i miejscu; A. E. Bottoms, P. Wiles, op. cit., s. 629.

${ }^{11}$ M. Felson, op. cit., s. 170-171.
} 
Drugi kierunek badań w obrębie kryminologii środowiskowej dotyczył miejsca zamieszkania sprawców przestępstw (źródłem informacji na ten temat były najczęściej dane zgromadzone w rejestrach policyjnych i aktach sądowych). Ich celem było ustalenie, w jakich miejscach lub obszarach zamieszkują sprawcy przestępstw, a następnie - przez analizę rozmaitych czynników, w tym kulturowych, społecznych, ekonomicznych - wskazanie, jakie czynniki środowiska przestrzennego oraz przestrzeni społecznej wpływają na taki stan rzeczy. W ramach tego nurtu badawczego nie udało się jednak wypracować wspólnej koncepcji, jako że niektóre z badań wskazuja, iż sprawcy dopuszczają się przestępstw w lepiej w znanych sobie okolicach ${ }^{12}$, inne - że z uwagi na większą anonimowość, mniejsze prawdopodobieństwo rozpoznania, a w konsekwencji słabszą nieformalną kontrolę społeczna, sprawcy są raczej skłonni popełniać przestępstwa dalej od swojego miejsca zamieszkania ${ }^{13}$.

Konkludując powyższe rozważania, należy podkreślić, że kryminologia środowiskowa przyczyniła się do lepszego poznania i zrozumienia przestrzennego wymiaru zjawiska przestępczości. Trzeba stwierdzić, że wpisujące się w nurt kryminologii środowiskowej badania przestępczości na terenie miast stanowia ważny instrument pozwalajacy z jednej strony na formułowanie wniosków dotyczących przyczyn zjawiska przestępczości w wielkim mieście i jego charakterystyki, z drugiej zaś - na przedstawianie koncepcji i strategii zapobiegania tej przestępczości. Badania dotyczące przestrzennych (geograficznych) aspektów przestępczości często bowiem pozwalają zidentyfikować pojawiajace się w przestępczości wielkomiejskiej schematy zachowań sprawców lub wzajemnego postępowania sprawcy i ofiary. Wskazanie elementów tychże schematów jest natomiast pierwszym krokiem na drodze do ich efektywnego eliminowania i zapobiegania im.

\section{PRAKTYCZNE WYKORZYSTANIE DOROBKU KRYMINOLOGII ŚRODOWISKOWEJ}

Do koncepcji środowiskowych w kryminologii zaliczane bywają również takie, które zwracają uwagę na związki nasilenia przestępczości z architektura (typem zabudowy) oraz rozplanowaniem przestrzennym miasta. Określone rozwiązania urbanistyczne mogą bowiem ułatwiać bądź utrudniać popełnianie przestępstw, gdyż wpływają zarówno na funkcjonowanie mechanizmów nieformalnej i formalnej kontroli społecznej, jak również na sam stopień trudności realizacji czynu przestępnego ${ }^{14}$.

Fundamentalne dla rozwoju tych koncepcji były prace Jane Jacobs i Oscara Newmana. Jacobs w książce Death and Life of Great American Cities stanow-

12 P. J. Brantingham, P. L. Brantingham, Patterns..., s. 362; A. E. Bottoms, P. Wiles, op. cit., s. 638 .

${ }_{13}$ M. Felson, M. Gottfredson, Social indicators of adolescent activities near peers and parents, „Journal of Marriage and the Family” 46, 1984, August, s. 709-714.

14 J. Błachut, A. Gaberle, K. Krajewski, op. cit., s. 107. 
czo skrytykowała ówczesne planowanie przestrzenne w amerykańskich miastach - przeciwstawiała się trendowi do sytuowania dzielnic mieszkalnych na obrzeżach miast, sformułowała też koncepcję „oczu na ulicy” (ang. eyes on the street), tzn. że im więcej osób przebywa w innych przestrzeniach miejskich, tym większy jest nadzór nad działaniami i zachowaniami jednostek, a w konsekwencji silniejsze mechanizmy nieformalnej kontroli społecznej ${ }^{15}$.

Koncepcja sformułowana przez Jacobs dała początek praktycznemu nurtowi określanemu jako New Urbanism. Jego przedstawiciele promuja konstruowanie w miastach otwartych, ogólnodostępnych przestrzeni, z klasycznymi przelotowymi, dwustronnie obudowanymi ulicami, gdzie obcy przechodnie na równi z mieszkańcami stanowią element naturalnego mechanizmu kontrolnego. Zwolennicy tego nurtu wskazuja, że tak ukształtowana przestrzeń miejska wpływać może na zmniejszenie liczby przestępstw przez zwiększenie nadzoru nad użytkownikami przestrzeni, promowanie ruchu pieszego i interakcji społecznych, a także zwiększenie poczucia wspólnoty. Znaczna ilość „oczu na ulicy” ma poprawiać funkcjonowanie mechanizmów nieformalnej kontroli społecznej i w konsekwencji prowadzić do redukcji przestępczości ${ }^{16}$.

Nieco inny pogląd na temat relacji między zabudową miejską a przestępczością wyraził Newman, który opierając się na przeprowadzonych badaniach, wskazywał, jak odpowiednie ukształtowanie zabudowy mieszkalnej może wzmocnić kontrolę mieszkańców nad ich lokalnym środowiskiem przestrzennym, a także jak idee „pozwalającej się obronić przestrzeni” moga zostać wdrożone w praktyce i przyczynić się do redukcji przestępczości ${ }^{17}$. Newman, w przeciwieństwie do Jacobs, opowiadał się za zamkniętymi i niedostępnymi strukturami przestrzennymi, w których mieszkańcy sprawuja naturalny nadzór, a fundamentalnym mechanizmem jest to, że niezwłocznie rozpoznają obcych i reagują na ich obecność. Podkreślając istotne znaczenie odpowiedniego projektowania przestrzeni miejskiej dla prewencji przestępczości, Newman skłaniał się ku strukturze wewnętrznych, obronnych, wyraźnie zamkniętych enklaw w postaci sięgaczy, dziedzińców z jednym tylko punktem dostępu ${ }^{18}$.

Koncepcja „pozwalającej się obronić przestrzeni” Newmana przywoływana jest najczęściej w literaturze jako leżąca u podstaw kierunku CPTED (ang. crime prevention through environmental design; tj. prewencja przestępczości

${ }^{15}$ J. Jacobs, Death and Life of Great American Cities, New York 1961; E. Midtveit, Crime prevention and exclusion: from walls to opera music, „Journal of Scandinavian Studies in Criminology and Crime Prevention" 6, 2005, s. 24-25.

${ }_{16}$ P. M. Cozens, New urbanism, crime and the suburbs: a review of the evidence, „Urban Policy and Research" 26(4), 2008, s. 430; zob. także: B. Czarnecki, W. Siemiński, Kształtowanie bezpiecznej przestrzeni publicznej, Warszawa 2004, s. 34.

${ }_{17}$ O. Newman, Defensible space: crime prevention through urban design, New York 1972; E. Midtveit, op. cit., s. 25.

${ }_{18}$ O. Newman, Defensible space...; B. Czarnecki, W. Siemiński, op. cit., s. 34 i 35; zob. także: P. Parnaby, Crime prevention through environmental design: discourses of risk, social control, and a neo-liberal context, „Canadian Journal of Criminology and Criminal Justice” 48(1), 2006, s. 3-4. 
przez kształtowanie bezpiecznej przestrzeni) ${ }^{19}$. Centralnym punktem koncepcji CPTED jest dążenie do takiego ukształtowania przestrzeni (zarówno publicznej, jak i w pewnej części prywatnej), które doprowadzi do poprawy bezpieczeństwa i redukcji przestępczości przez zlikwidowanie „okazji” do popełnienia przestępstwa. W ramach CPTED okazje sa bowiem ujmowane jako sprzyjające popełnieniu przestępstwa okoliczności związane z zabudowa, rozłożeniem ulic, oświetleniem oraz innymi elementami środowiska przestrzennego ${ }^{20}$.

Przez wiele lat funkcjonowania strategia CPTED była systematycznie wzbogacana o wnioski płynące z kolejnych badań i obserwacji, jednakże jej podstawowe elementy pozostają niezmienne. Na zapobieganie przestępczości przez kształtowanie bezpiecznej przestrzeni składają się w pierwszej kolejności następujace elementy: kontrola dostępu, nadzór, wyodrębnienie terenu oraz zarządzanie nim i konserwacja ${ }^{21}$. Stosowanie strategii CPTED musi być jednak procedura wieloetapowa. W pierwszej kolejności w odniesieniu do analizowanej przestrzeni musi zostać dokonana ocena potencjalnych zagrożeń związanych z nieprawidłowa zabudowa, zagospodarowaniem i ukształtowaniem okolicy. Ewaluacja ta dotyczy przede wszystkim wskazania, które elementy przestrzeni fizycznej stwarzać mogą okazje do popełnienia przestępstwa. Następnie należy opracować rozwiązania, które mają służyć minimalizowaniu tychże potencjalnych okazji. Finalnym etapem jest wdrożenie zaprojektowanych rozwiązań w życie ${ }^{22}$. Efektywne realizowanie strategii CPTED wymaga zatem skoordynowanego współdziałania specjalistów z różnych branż i dziedzin nauki: kryminologów, architektów, policji, a także zarządzających przestrzenią dozorców i administratorów.

Prace Jacobs oraz Newmana oraz praktyczne strategie wywodzące się z ich koncepcji składają się na tzw. sytuacyjne zapobieganie przestępczości ${ }^{23}$. Termin ten odnosi się do zapobiegania przestępczości nie tyle przez oddziaływanie na społeczeństwo czy jego instytucje lub agendy, ile przez likwidowanie fizycznych okazji i możliwości popełnienia przestępstwa ${ }^{24}$. W literaturze wskazuje się bowiem, że pewne rodzaje miejsc ze względu na swój

${ }^{19}$ Czytelnika warto odesłać do pierwszych publikacji w tym zakresie: C. R. Jeffery, Crime Prevention through Environmental Design, Beverly Hills, CA: Sage Publications 1971; S. Angel, Discouraging Crime through City Planning, Berkeley 1968; R. Atlas, 21st Century Security and CPTED: Designing for Critical Infrastructure Protection and Crime Prevention, CRC Press, Taylor \& Francis Ltd 2008; T. Crowe, Crime Prevention through Environmental Design, 2nd edn., Boston 2000.

${ }^{20}$ Tak m.in. E. M. Walsh, Crime prevention through environmental design, „Journal of Housing and Community Development” 56(4), 1999, s. 42; R. Draper, E. Cadzow, Crime prevention through environmental design, „PEB Exchange, Programme on Educational Building” 2004, no. 13 , s. 9.

21 E. H. Ziegler, American cities, urban planning, and place-based crime prevention, „Urban Lawyer” 39(4), 2007, s. 861-862; K. Łojek, Zapobieganie przestepczości przez ksztattowanie bezpiecznej przestrzeni, cz. 1, „Przegląd Policyjny” 14, 2004, nr 1-2, s. 89.

22 P. Parnby, op. cit., s. 4 i 6-9.

${ }^{23}$ J. Błachut, A. Gaberle, K. Krajewski, op. cit., s. 107.

24 E. A. Fattah, Some reflections on crime prevention strategies in large metropolitan centres of the 21st century, „European Journal of Crime, Criminal Law and Criminal Justice” 7(2), 1999, s. 143 . 
charakter, położenie, zabudowę, specyficzną funkcję, jaką spełniają, same $\mathrm{W}$ sobie stanowią przestrzeń sprzyjająca popełnianiu przestępstw ${ }^{25}$. Warte jest $\mathrm{w}$ tym kontekście podkreślenia stanowisko, że w procesie zapobiegania przestępczości „nie można tracić z pola widzenia technicznych środków, stanowiących nie tyle "reakcję» na przestępczość, ile »blokadę« dla takich zachowań" 26 .

Zagadnienie sytuacyjnego zapobiegania przestępczości można ujmować wassko lub szeroko. Ujęcie wąskie dotyczy stosowania środków, polegających na zmianie środowiska naturalnego przez np.: tworzenie fizycznych zapór (np. szyb antywłamaniowych), instalację systemów alarmowych oraz usunięcie warunków sprzyjajacych zachowaniom przestępnym. Mówiąc o szerokim ujęciu omawianego zagadnienia, należy dodatkowo wskazać utrudnienia prawne mające na celu m.in. ograniczenie dostępu do przedmiotów służących popełnianiu przestępstw (np. broni), a także niedopuszczanie do pewnych typów działalności, które wymagają posiadania określonych cech lub kwalifikacji, osób, które takowych nie posiadaja ${ }^{27}$.

Należy dla porządku wspomnieć, że elementem uzupełniającym zapobieganie sytuacyjne jest dążenie do aktywizacji zbiorowości lokalnych w prewencji przestępczości. Dążenia te opierają się na założeniu, że nieformalna kontrola społeczna sprawowana przez zbiorowości lokalne może tworzyć swoiste „pole ochronne”, w którym jednostki sygnalizują wystapienie zagrożenia przestępstwem lub też popełnienie przestępstwa. Jasne jest, że sprawne funkcjonowanie takiego „systemu” zależy jednak od spełnienia określonych warunków ${ }^{28}$. Aktywizacja zbiorowości lokalnych bywa nazywana jednym z elementów tzw. drugiej generacji zapobiegania przestępczości przez kształtowanie bezpiecznej przestrzeni (ang. second generation CPTED) ${ }^{29}$.

Szersze omówienie zasad sytuacyjnej prewencji przestępczości czy też koncepcji CPTED przekracza ramy niniejszego opracowania, niemniej w świetle przedstawionych wyżej argumentów jawi się jako oczywiste, że same tylko informacje o tym, gdzie są popełniane przestępstwa określonego rodzaju, nie stanowi właściwie żadnej wartości. Jeżeli taka wiedza ma w jakikolwiek sposób przysłużyć się zapobieganiu przestępczości, to wymaga przeprowadzenia pogłębionych badań, stanowiących choćby próbę odpowiedzi na pytanie, czym charakteryzuje się dana przestrzeń, w której stwierdzono zwiększone nasilenie przestępczości.

${ }^{25}$ P. L. Brantingham, P. J. Brantingham, Criminality of place. Crime generators and crime attractors, w: K. Moss (ed.), Crime Reduction. Critical Concepts in Criminology, vol. 2: Motivation of the Criminal Inclination, New York 2009, s. 43 i n.

${ }^{26}$ J. Błachut, A. Gaberle, K. Krajewski, op. cit., s. 494.

${ }^{27}$ Ibidem, s. 494; P. L. Brantingham, P. J. Brantingham, W. Taylor, Situational crime prevention as a key component in embedded crime prevention, „Canadian Journal of Criminology and Criminal Justice” 47(2), 2005, s. 276-279; P. Cozens, Crime prevention through environmental design in western Australia: planning for sustainable urban futures, „International Journal of Sustainable Development and Planning” 3(3), 2008, s. 282.

${ }^{28}$ J. Błachut, A. Gaberle, K. Krajewski, op. cit., s. 495.

${ }^{29}$ P. Cozens, Crime prevention..., s. 281 i 282; D. Weisburd et al., Does crime just move around the corner? A controlled study of spatial displacement and diffusion of crime control benefits, „Criminology” 44(3), 2006, s. 572-584. 


\section{MIEJSCA SZCZEGÓLNEGO ZAGROŻENIA W KONTEKŚCIE USTAWY O PRZECIWDZIALANIU ZAGROŻENIOM PRZESTĘPCZOŚCIĄ NA TLE SEKSUALNYM}

Ustawa o przeciwdziałaniu zagrożeniom przestępczością na tle seksualnym została uchwalona 13 maja 2016 r. $^{30}$; zgodnie z jej założeniami ma przeciwdziałać przestępczości seksualnej przez przewidziane w jej przepisach instytucje i instrumenty prawne. Sztandarowe rozwiąanie ww. aktu normatywnego, jakim ma być rejestr sprawców przestępstw seksualnych, było już przedmiotem krytyki autora ${ }^{31}$, natomiast w ramach niniejszej publikacji warto poświęcić nieco miejsca „mapie zagrożeń przestępstwami na tle seksualnym”. Zgodnie z art. 22 u.p.p.s.:

Określenie miejsc szczególnego zagrożenia przestępczością na tle seksualnym następuje $\mathrm{w}$ formie dostępnej publicznie policyjnej mapy zagrożeń przestępstwami na tle seksualnym, o której mowa w art. 21o ustawy z dnia 6 kwietnia 1990 r. o Policji.

Z kolei przywołany art. 21o ustawy o Policji (dalej jako: u.o.p.) stanowi, że:

ust. 1. Komendant Główny Policji prowadzi policyjną mapę zagrożeń przestępstwami na tle seksualnym zawierającą aktualne informacje o miejscach szczególnego zagrożenia przestępstwami przeciwko wolności seksualnej, wymienionymi w rozdziale XXV Kodeksu karnego.

Mapa zagrożeń ma być dostępna publicznie za pośrednictwem strony internetowej (art. 210 ust. 2 u.o.p.), natomiast zagadnieniom wykonawczym ma zostać poświęcone stosowne rozporządzenie (art. 210 ust. 3 u.o.p.).

U podstaw wszystkich rozwiązań wprowadzanych komentowaną ustawa legło przekonanie, że „przestępczość dokonywana z pobudek seksualnych jest problemem narastajacym" ${ }^{32}$. Zdaniem projektodawcy:

w celu doprowadzenia do odczuwalnych dla społeczeństwa zmian w zagrożeniu przestępczością na tle seksualnym, w tym: zmniejszenia liczby zagrożeń, ograniczenia tego rodzaju przestępczości, poprawy poczucia bezpieczeństwa członków społeczności lokalnych, obniżenia poziomu subiektywnego poczucia lęku, a także zmniejszenia niebezpieczeństwa wiktymizacji, w art. 21 oraz art. 24 projektu przewidziano utworzenie policyjnej mapy zagrożeń przestępstwami na tle seksualnym, zawierającej aktualne informacje o miejscach szczególnego zagrożenia przestępstwami przeciwko wolności seksualnej i obyczajności, wymienionymi w rozdziale XXV Kodeksu karnego ${ }^{33}$.

Autorzy projektu ustawy, mając świadomość nowatorskiego charakteru proponowanych rozwiązań, sami podkreślali, że:

Pojęcie mapy zagrożeń jest dość nowe. Najczęściej jest ona rozumiana jako wykaz zagrożeń zewnętrznych i wewnętrznych o różnym charakterze (tu: kryminalnym) oddziałujących na

${ }^{30}$ Dz. U. 2016, poz. 862 (dalej także jako: u.p.p.s.).

${ }^{31}$ M. Bocheński, Criminological problems of registers of sexual offenders: remarks on the sexual offences act of 13 may 2016, „Problems of Forensic Sciences” 105 (CV), 2016, s. 370-393.

32 Rządowy projekt ustawy o przeciwdziałaniu zagrożeniom przestępczością na tle seksualnym, Druk Sejmowy Sejmu VIII Kadencji nr 189, http://www.sejm.gov.pl/Sejm8.nsf/druk. xsp?nr=189, Uzasadnienie projektu s. 1 [dostęp: 30.11.2017].

33 Ibidem, s. 7. 
procesy o żywotnym znaczeniu dla bezpieczeństwa i funkcjonowania społeczeństwa. Istotnym aspektem w kontekście tworzenia mapy zagrożeń jest konieczność kompleksowego spojrzenia na chronione dobra. Niezależnie od określenia niebezpieczeństw mapa zagrożeń musi identyfikować także krytyczne procesy i przewidywać realne niebezpieczeństwo dla chronionych dóbr. W przypadku projektowanych przepisów chodzi o możliwość oceny, jak sąsiedztwo wpływa na nasze bezpieczeństwo, a zwłaszcza czy w najbliższym sąiedztwie miały miejsce incydenty wpływajace na poczucie zagrożenia. W ten sposób jest podejmowany wysiłek w celu zapewnienia możliwie najpełniejszego bezpieczeństwa. W konsekwencji zostaja stworzone warunki do zwiększenia zaangażowania społeczności lokalnych w procesy tzw. zarządzania bezpieczeństwem poprzez podniesienie poziomu ich świadomości, co pozwala na prostsze stworzenie systemu bezpieczeństwa i uzyskanie wymiernych efektów (ograniczenie przestępczości). Określenie ryzyka - sporządzenie mapy zagrożeń - jest pierwszym elementem cyklu zarządzania bezpieczeństwem ${ }^{34}$.

Nie sposób w tym miejscu nie zwrócić uwagi, że - w warstwie deklaracji projektodawca zdawał sobie sprawę ze złożoności zagadnienia. Wskazują na to stwierdzenia, że mapa zagrożeń „musi identyfikować krytyczne procesy i przewidywać realne niebezpieczeństwo dla chronionych dóbr", a także przekonanie, że przez wprowadzenie ustawy w omawianym zakresie „zostają stworzone warunki do zwiększenia zaangażowania społeczności lokalnych w procesy tzw. zarządzania bezpieczeństwem". Jak wskazano w uzasadnieniu projektu ustawy: „określenie ryzyka - sporządzenie mapy zagrożeń - jest pierwszym elementem cyklu zarządzania bezpieczeństwem”.

W kontekście tego rodzaju deklaracji zasadne byłoby odniesienie się do uchwalonych przepisów na dwóch płaszczyznach: czy są one przystajace do specyfiki „przestrzennego wymiaru” przestępstw seksualnych oraz w jaki sposób przebiegać będzie praktyczna realizacja tak zadanych celów ustawy?

\section{MIEJSCA „SZCZEGÓLNEGO ZAGROŻENIA” PRZESTĘPSTWAMI SEKSUALNYMI W ŚWIETLE BADAŃ EMPIRYCZNYCH}

Oceny pierwszej z sygnalizowanych kwestii pozwalaja w pewnej mierze dokonać dostępne dane empiryczne, w tym także wyniki badań przeprowadzonych przez autora ${ }^{35}$. Prezentowane $\mathrm{w}$ niniejszym artykule wyniki badań stanowią część projektu badawczego „Formy prawnokarnej reakcji wobec sprawców przestępstw seksualnych w Polsce” finansowanego z grantu Narodowego

${ }^{34}$ Ibidem, s. 8.

${ }^{35}$ Zob. m.in. E. Bieńkowska, Wptyw zachowania ofiary na rozstrzygnięcie sprawy o zgwatcenie, Wrocław 1984, s. 77-83; zob. także: M. Bocheński, Prawnokarna reakcja wobec sprawców przestepstw $z$ art. 197 KK $i$ art. 200 KK $w$ świetle teorii $i$ badań empirycznych, Warszawa 2016; J. Warylewski, Reakcja karna na przestepstwa seksualne, „Przegląd Więziennictwa Polskiego” 2007, nr 54, s. 55. M. Mozgawa, M. Budyn-Kulik, Prawnokarne aspekty pedofilii. Analiza dogmatyczna i wyniki badań empirycznych, „Czasopismo Prawa Karnego i Nauk Penalnych” 2006, z. 2, s. 43-78; M. Mozgawa, P. Kozłowska-Kalisz, Zgwałcenie $w$ matżeństwie (w świetle badań empirycznych), w: M. Mozgawa (red.) Przestepstwo zgwatcenia, Warszawa 2012, s. 217-242. 
Centrum Nauki nr 2013/09/N/HS5/04247. Badania prowadzone były metoda badania akt spraw sądowych o przestępstwa z art. 197 k.k. i art. 200 k.k. zgodnie z zaprojektowanym do tego celu kwestionariuszem. Zostały one przeprowadzone w wydziałach karnych sądów okręgowych i rejonowych w Katowicach i w Krakowie. Za kryterium doboru akt do badań przyjęto datę wpływu do sądu sprawy z art. 197 k.k. lub 200 k.k. w okresie od 1 stycznia 2006 r. do 31 grudnia 2012 r., przy czym ostatecznie - ze względu na cel i zakres projektu badawczego - brano pod uwagę jedynie sprawy, w których zapadł prawomocny wyrok skazujący za ww. przestępstwa. Badane sprawy dotyczyły ogółem 289 czynów (190 zgwałceń oraz 99 czynów z art. 200 k.k.).

W przypadku zgwałceń w niemal jednej trzeciej przypadków (62 czyny $-32,6 \%$ wszystkich tego rodzaju przestępstw) czyn został popełniony w miejscu publicznym ${ }^{36}$. Z kolei blisko dwie trzecie tego rodzaju przestępstw zostało popełnionych w miejscu prywatnym, przy czym: 36 (18,9\%) we wspólnym mieszkaniu; 37 (19,5\%) w mieszkaniu sprawcy; 20 (10,5\%) w mieszkaniu ofiary; $11(5,8 \%) \mathrm{w}$ samochodzie sprawcy oraz $22(11,6 \%) \mathrm{w}$ innym miejscu prywatnym ${ }^{37}$. O ile w przypadku zgwałceń nieco ponad 1/3 czynów została popełniona w miejscach publicznych, o tyle w przypadku czynów z art. 200 k.k. było to jedynie 19 przypadków (19,1\%). Spośród wszystkich czynów wykorzystywania seksualnego małoletnich w $70 \%$ przypadków miejscem popełnienia przestępstwa było miejsce prywatne: w 38 przypadkach $(38,4 \%)$ mieszkanie sprawcy; w 17 przypadkach (17,2\%) wspólne mieszkanie sprawcy i ofiary; w 7 przypadkach $(7,1 \%)$ mieszkanie pokrzywdzonego oraz w 4 przypadkach $(4,0 \%)$ samochód sprawcy oraz taka sama liczba czynów w innym miejscu prywatnym.

Analiza powyższych danych prowadzi do wniosku, że wśród omawianych przestępstw zdecydowana większość z nich popełniana jest w miejscach, które można określić jako przestrzeń prywatna. W przypadku zgwałceń taka sytuacja występuje szczególnie często (blisko 3/4) w przypadku takich czynów, które poprzedzone są interakcją sprawcy i ofiary, a zatem nawiązaniem jakiejśs relacji lub choćby szczątkowej znajomości ${ }^{38}$. Jeżeli nawet miejscem nawiązania interakcji jest przestrzeń publiczna, to z czasem przenosiła się ona do przestrzeni prywatnej, gdzie ostatecznie dochodziło do popełnienia przestępstwa. Można w tym miejscu zaryzykować stwierdzenie, że nawet jeśli finalnie

\footnotetext{
${ }^{36}$ Kategoria ta została utworzona po przeprowadzeniu badań, na podstawie uzyskanych z akt sprawy danych; konkretnymi lokalizacjami, które złożyły się na tę kategorię, były ulice, place, tereny zielone, jak również bramy budynków, klatki schodowe, torowiska, nasypy kolejowe, dyskoteki oraz inne miejsca, do których nieograniczony dostęp ma nieograniczona liczba osób.

${ }^{37} \mathrm{~W}$ tej kategorii ujęto takie miejsca, jak: mieszkanie znajomego, altana działkowa, domek letniskowy, pokój w hotelu lub w pensjonacie, cela w zakładzie karnym, gabinet lekarski.

${ }^{38}$ Autor tematyce zgwałceń interakcyjnych, miejsca podejmowania interakcji oraz miejsca popełnienia przestępstwa zgwałcenia poświęcił wiele miejsca w niepublikowanej pracy magisterskiej (M. Bocheński, Kryminologiczna i wiktymologiczna problematyka przestępstwa zgwatcenia, ze szczególnym uwzględnieniem relacji pomiędzy ofiara, sprawca $i$ miejscem popetnienia czynu, UJ, Kraków 2010, s. 92-116; zob. także: E. Bieńkowska, Wptyw zachowania..., s. 77-83; J. Warylewski, Reakcja karna..., s. 55).
} 
sprawca zgwałcenia stosował wobec ofiary jeden z opisanych w art. 197 k.k. sposobów działania, to nierzadko podejmował wcześniej zachowania zmierzajace do zdobycia jej zaufania ${ }^{39}$ i znalezienia się z nią w miejscu prywatnym, tj. niedostępnym dla nieograniczonego kręgu osób.

Nie sposób nie wskazać w tym miejscu na specyficzne (z perspektywy kryminologicznej) zgwałcenia, których sprawcami byli małżonkowie lub partnerzy ofiary - w takich przypadkach ich mieszkanie jest miejscem, w którym wspólnie przebywaja relatywnie często, a zatem ofiara jest stale „dostępna” dla sprawcy, który ma niemal nieograniczone okazje do popełnienia przestępstwa $^{40}$. W badanych sprawach zgwałcenia małżeńskie/partnerskie w zdecydowanej większości popełniane były we wspólnym mieszkaniu sprawcy i ofiary, podobnie jak zgwałcenia popełniane przez jedno z rodziców/opiekuna. W przypadku zgwałceń popełnianych przez innego (niż jedno z rodziców/opiekun) członka rodziny najczęstszym miejscem popełnienia przestępstwa jest mieszkanie sprawcy ${ }^{41}$.

Z kolei zgwałcenia popełniane w miejscach publicznych (blisko $1 / 3$ czynów zbadanych przez autora) jawią się w przeważającej części jako czyny niezaplanowane i nieprzemyślane, popełniane pod wpływem chwili, nagłego impulsu, który skłaniał sprawcę do realizacji swoich popędów. Bez względu na to, czy motywem napędzającym działanie sprawcy było pobudzenie seksualne czy też skłonność do zachowań agresywnych, realizacja tych pobudek była dla sprawcy ważniejsza niż zapewnienie sobie bezpieczeństwa i bezkarności ${ }^{42}$. Co do czynów popełnianych w miejscach publicznych nie sposób nie odnieść wrażenia, że sprawca często nie miał możliwości doprowadzenia ofiary w miejsce prywatne - wykorzystywał natomiast ciemność bądź ustronność miejsca ${ }^{43}$.

W kwestii czynów wobec małoletnich należy stwierdzić, że ostatnio wszelkie formy nadmiernego, nacechowanego seksualnie zainteresowania dorosłych małoletnimi mogą zwracać uwagę osób postronnych, stąd należy domniemywać, że w przestrzeni publicznej tego rodzaju zachowania byłyby obarczone znacznym ryzykiem ich dostrzeżenia przez ewentualnych świadków. Z tego względu znaczna przewaga przestrzeni prywatnej w ogólnej liczbie badanych przez autora spraw o przestępstwa z art. 200 k.k. była w dużej mierze możliwa do przewidzenia. W sytuacjach, w których sprawcami tych czynów byli

\footnotetext{
${ }^{39}$ Najczęściej ofiara, nie zdając sobie sprawy z rzeczywistych zamiarów sprawcy, sama i z własnej woli udawała się do jego miejsca zamieszkania bądź też wpuszczała go do swojego mieszkania. Interakcja pomiędzy sprawcą i ofiara przestępstwa była zresztą nierzadko rozciagnięta w czasie, sam zaś sprawca nie od razu podejmował zachowanie przestępne (bądź dlatego, że nie od początku przebywania z ofiarą miał zamiar dokonania jej zgwałcenia, bądź też z uwagi na podejmowanie działań mających w pierwszej kolejności na celu skłonienie ofiary do dobrowolnego podjęcia aktywności seksualnej).

${ }^{40}$ M. Mozgawa, P. Kozłowska-Kalisz, op. cit., s. 217-242.

${ }^{41}$ Por. E. Bieńkowska, op. cit., s. 77-83.

${ }^{42}$ Podobnie charakteryzuje tego rodzaju czyny E. Bieńkowska w artykule, O wiktymo- $i$ kryminogennej roli alkoholu w genezie zgwatcenia, „Przegląd Prawa Karnego” 1996, nr 14-15, s. 36.

${ }^{43}$ M. Bocheński, Prawnokarna reakcja..., s. 324-330, zob. także: idem, Kryminologia środowiskowa i jej znaczenie dla badań nad przestęstwem zgwatcenia, „Przegląd Więziennictwa Polskiego" 2012, nr 74-75, I-II kwartał, s. 45-68.
} 
członkowie rodziny ofiary, z perspektywy sprawcy - nie ma potrzeby ryzykować popełnienia czynu na zewnątrz, podczas gdy w miejscach prywatnych, w których sprawcy wspólnie z ofiarami zamieszkuja, zdarzało się aż nazbyt wiele okazji do popełnienia czynu. Nawet zwabienie małoletniego do miejsca zamieszkania sprawcy nie wymagało zwykle podejmowania przezeń skomplikowanych zabiegów, a sprowadzało się najczęściej do wykorzystania ufności i niedoświadczenia dziecka ${ }^{44}$.

Z kolei grupa czynów, w przypadku których dochodziło do dobrowolnego współżycia młodych ludzi (z których jedno miało mniej niż 15 lat), w ponad 2/3 przypadków popełniana była w mieszkaniu sprawcy, ofiary lub wspólnym. Nie sposób wykluczyć, że młodzi ludzie (najczęściej „chodzący ze sobą”) szukają intymności w swoich (często pierwszych) doświadczeniach seksualnych i z tego względu wybierają miejsce prywatne na podjęcie aktywności seksualnej ${ }^{45}$.

W zakresie bardziej szczegółowych danych, których omówienie przekraczałoby ramy niniejszej publikacji, zainteresowanego czytelnika wypada odesłać do stosownej literatury ${ }^{46}$, natomiast w tym miejscu zasadne jest rozważenie - jakie znaczenie z perspektywy mapy zagrożeń przestępstwami na tle seksualnym mają przywołane dane.

\section{KONKLUZJE}

Jeżeli wspomniany instrument, o którym mowa w art. 22 u.p.p.s., miałby obrazować, w których miejscach lub obszarach na mapie danego terenu zgłaszane są przestępstwa seksualne, to można a priori domniemywać, że „zagrożenie" będzie odpowiednio większe w tzw. dzielnicach sypialniach (gdzie jest więcej mieszkań, a w konsekwencji więcej okazji do popełnienia przestępstwa), a mniejsze choćby w centrum miast; a także większe w miastach niż na terenach wiejskich ${ }^{47}$. Zresztą samo wskazanie (zaznaczenie na mapie) miejsc szczególnego zagrożenia przestępczością seksualną nijak - samo w sobie - nie

${ }^{44}$ M. Bocheński, Prawnokarna reakcja..., s. 324-330; zob. także: M. Beisert, Pedofilia. Geneza $i$ mechanizm zaburzenia, Sopot 2012, s. 101-108; M. Mozgawa, M. Budyn-Kulik, Prawnokarne aspekty..., s. 43-78.

45 Zob. M. Mozgawa, M. Budyn-Kulik, op. cit., s. 69.

${ }^{46}$ M. Bocheński, Prawnokarna reakcja...; M. Beisert, op. cit.; M. Mozgawa, M. Budyn-Kulik, op. cit., s. 43-78; G. C. N. Hall, R. Hirschman, Sexual aggression against children: a conceptual perspective of etiology, „Criminal Justice and Behavior” 19(1), 1992, s. 8-23; R. C. W. Hall, A profile of pedophilia: definition, characteristics of offenders, recidivism, treatment outcomes, and forensic issues, „Mayo Clinic Proceedings” 82(4), 2007, s. 457-471; M. C. Seto, Pedophilia, „Annual Review of Clinical Psychology” 5, 2009, s. 391-407; M. C. Seto, Pedophilia and sexual offenses against children, „Annual Review of Sex Research” 15, 2004, s. 321-361; M. C. Seto, Pedophilia and Sexual Offending against Children. Theory, Assessment and Intervention, Washington, DC, 2008.

${ }^{47}$ T. Hanausek, A. Marek, J. Widacki, Zgwatcenia, Warszawa 1976, s. 13-14; Z. Marek, J. Widacki, Wiktymologia zgwatcenia, „Przegląd Lekarski” 31, 1974, nr 5, s. 31; E. Bieńkowska, Wpływ zachowania...; B. Gruszczyńska, Przemoc wobec kobiet w Polsce. Aspekty prawnokryminologiczne, Warszawa 2007, s. 60 i n.; M. Marczewski, Obraz statystyczny przestepstw z art. 197 k.k., w: M. Mozgawa (red.), Przestepstwo zgwatcenia, Warszawa 2012, s. 197-213. 
może odnieść skutku w postaci prewencji przestępczości. A należy przypomnieć, że - zdaniem projektodawców - mapy przestępczości miały realizować takie właśnie cele, jak:

zapewnienie możliwie najpełniejszego bezpieczeństwa, [...] zwiększenie zaangażowania społeczności lokalnych $\mathrm{w}$ procesy tzw. zarządzania bezpieczeństwem [...], co pozwala na prostsze stworzenie systemu bezpieczeństwa i uzyskanie wymiernych efektów (ograniczenie przestępczości $)^{48}$.

Tymczasem nie można tracić z pola widzenia, że w Polsce istnieje już Krajowa Mapa Zagrożeń Bezpieczeństwa (dalej jako: KMZB) ${ }^{49}$ obrazująca miejsca, których dotyczą zgłoszenia oraz informacje gromadzone w policyjnych systemach informatycznych, pozyskiwane od społeczeństwa, w tym w szczególności od internautów $\mathrm{z}$ wykorzystaniem platformy wymiany informacji ${ }^{50}$. Jako że ocena wspomnianego instrumentu nie stanowi przedmiotu niniejszych rozważań, zasadne jest wspomnieć tylko, że obecnie zdecydowana większość zagrożeń bezpieczeństwa uwidoczniona na KMZB jest związana z ruchem drogowym (m.in. nieprawidłowym parkowaniem). Analizując poszczególne „zagrożenia”, nie sposób nie odnieść wrażenia, że niektóre z nich są w istocie relatywnie mało „zagrażające”, a ich umiejscowienie na KMZB może odnosić efekt odwrotny do zamierzonego, a to w postaci potęgowania poczucia zagrożenia i lęku przed przestępczościa.

Jeżeli mapa zagrożeń przestępstwami na tle seksualnym będzie skonstruowana na podobnej, czy też tożsamej, zasadzie jak KMZB, to trudno ja będzie samą w sobie określić jako potencjalnie skuteczne narzędzie prewencji przestępczości seksualnej. Jeśli w ramach działań (opartych na komentowanej ustawie) zmierzających do poprawy bezpieczeństwa obywateli jedynym działaniem Policji będzie publikowanie miejsc wskazywanych jako miejsca popełnienia przestępstwa w ramach zgłoszeń obywateli czy też działań własnych organów ścigania, to z cała pewnościa zadany cel wprowadzanych przepisów nie zostanie osiagnięty. Trzeba bowiem pamiętać, że przestępstwa seksualne mają swoją specyfikę, której uwzględnienia wymaga projektowanie działań prewencyjnych. Nie można tracić z pola widzenia, że - z perspektywy fenomenologii przestępczości - istnieją zasadnicze różnice pomiędzy czynami popełnianymi w przestrzeni prywatnej a tymi, do których dochodzi w przestrzeni publicznej ${ }^{51}$. Podobnie najczęściej nijak nie przystają do siebie przestępstwa seksualne, które można określić jako „wewnątrzrodzinne”, i te, których sprawcami są osoby obce względem ofiar ${ }^{52}$. Rozbieżności te muszą stać się podstawa stosownych działań prewencyjnych, które są inne w przypadku przeciwdzia-

${ }^{48}$ Rządowy projekt ustawy o przeciwdziałaniu zagrożeniom przestępczością na tle seksualnym, Druk Sejmowy Sejmu VIII Kadencji nr 189,http://www.sejm.gov.pl/Sejm8.nsf/druk.xsp? nr=189, Uzasadnienie projektu, s. 1 [dostęp: 30.11.2017].

49 Zob. http://www.policja.pl/pol/mapa-zagrozen-bezpiecze/33880,dok.html [dostęp: 30.11.2017].

${ }_{50}$ Zob. http://www.policja.pl/pol/mapa-zagrozen-bezpiecze/33880,dok.html [dostęp: 30.11.2017].

51 M. Bocheński, Prawnokarna reakcja..., s. 324-330.

52 Ibidem, s. 324-330; M. Płatek, Karnoprawne modele przeciwdziałania przemocy w rodzinie, „Archiwum Kryminologii” 29-30, 2007-2008, s. 601-616 oraz powołana tam literatura. 
łania przemocy w rodzinie ${ }^{53}$, a inne gdy w grę wchodzi sytuacyjna prewencja przestępczości w miejscach publicznych ${ }^{54}$. Oba rodzaje działań prewencyjnych oczywiście się nie wykluczaja, natomiast trzeba mieć świadomość, że samo uwidocznienie miejsc „szczególnego zagrożenia” nie będzie miało żadnego znaczenia, gdy w następstwie zdefiniowania takich lokalizacji nie zostaną podjęte szeroko zakrojone działania mające za przedmiot także działania społeczne i edukacyjne, jak również urbanistyczne wpisujące się w nurt CPTED.

Konkludując, należy stwierdzić, że mapa zagrożeń przestępstwami na tle seksualnym - w kontekście przywołanego dorobku kryminologii środowiskowej - może stanowić ważny punkt wyjścia do dalszych dociekań badawczych i działań z zakresu prewencji przestępczości. Jeżeli jednak takowe nie zostana podjęte, to pozostanie instrumentem o znikomej wartości poznawczej i z dużym prawdopodobieństwem nikłym znaczeniu praktycznym, który zamiast przyczyniać się do ograniczenia przestępczości seksualnej może potęgować jedynie poczucie zagrożenia wśród mieszkańców oraz zwiększony lęk i strach przed przestępczością seksualną.

dr Maciej Bocheński

Krakowska Izba Adwokacka

maciej.bochenski@adwokatura.krakow.pl

THE MAP OF THE THREATS OF SEXUAL OFFENCES AS A TOOL OF SITUATIONAL CRIME PREVENTION IN POLAND - CRITICAL REMARKS

\section{Summary}

The Act on Counteracting the Threat of Sexual Offences was enacted on 13 May 2016. One of the solutions it has introduced is a map of the threats of sexual offences. While the construction of this kind of tool for analysing the dimension and the phenomenology of crime does not raise any criticism from the point of view of the science of criminology, the implementation of this solution in Poland does not seem adequate for the intended purpose. This article assesses the Polish solutions regarding the drawing of a map of the threats of sexual offenses in the context of the acquis and the current findings of environmental criminology, including in particular crime prevention through environmental design and the shaping of situational crime prevention.

\footnotetext{
53 M. Płatek, op. cit., s. 601-616.

${ }_{54}$ Zob m.in. P. L. Brantingham, P. J. Brantingham, W. Taylor, op. cit., s. 276-279.
} 
